\title{
IAMJ
}

INTERNATIONAL

AYURVEDIC

MEDICAL JOURNAL

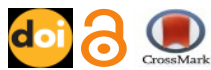

Review Article

ISSN: 23205091

Impact Factor: 5.344

\section{AN INSIGHT INTO AYURVEDIC VIEW OF SARS -COVID - 19}

\author{
Sreelakshmi S', Varghese Jibi², Manna Mathew ${ }^{3}$, Priyanka Yadav ${ }^{4}$ \\ ${ }^{1}$ PG Scholar, Department of Kayachikitsa, ${ }^{2}$ Associate Professor, Department of Kayachikitsa, \\ ${ }^{3} \mathrm{PG}$ Scholar, Department of Dravyaguna, ${ }^{4} \mathrm{PG}$ Scholar, Department of Kayachikitsa, \\ Dr. D. Y. Patil Vidyapeeth, D. Y. Patil college of Ayurveda \& Research Centre, Pimpri - Pune -18, Maharashtra, \\ India
}

Email: drsreelakshmisobhanadhan93@gmail.com

https://doi.org/10.46607/iamj0807172020

(Published online: July 2020)

Open Access

(C) International Ayurvedic Medical Journal, India 2020

Article Received: 19/06/2020 - Peer Reviewed: 21/06/2020 - Accepted for Publication: 01/07/2020

Check for updates

\section{ABSTRACT}

The Covid - 19 pandemic is defining the global health crisis of our time and occurs to be the greatest challenge. The number of people getting affected and deaths are raising daily throughout the world. COVID-19 is the infectious disease caused by the most recently discovered Corona virus. The situation is much more than a health crisis with a potential to create devastating situations at social, economic, and political levels. Till date, no effective management to address this infection has been identified and attempts are being made to integrate a few traditional interventions along with standard treatment protocols of COVID-19. Ayurveda's extensive knowledge is based on preventive care, health measures and boosting immunity. Contribution of Ayurveda in the management of various communicable and non-communicable diseases cannot be undermined. Through its wider concepts and treatment modalities, it has greater potential to address such situations. Awareness about the mode of spread of this disease is recommended highly to prevent oneself from falling prey to the disease. The large resource of timetested traditional knowledge has to be used for the benefit of mankind. In addition to the personal hygiene and social distancing measures, it is of immense importance to improve individual's natural defence system (immunity). Ayurveda can play a major role in mitigating the spread of COVID -19 by implementing some lifestyle 
changes along with simple herbal medications and procedures by properly classifying and distinguishing the stage of the disease.

Keywords: Ayurveda, Immunity, COVID 19

\section{INTRODUCTION}

The global health crisis of the moment has been known by "the COVID-19 pandemic". The number of patients affected, and deaths are raising day by day. The whole world has been tremendously affected by this ill issue and as a result, the whole world's economic, social and political condition at present, is in dilemma. After second world war, this scenario ends up as a greatest challenge. This August marks the $75^{\text {th }}$ anniversary of the conclusion of world war-II. In history's most destructive war,3\% of world population died, thousands were killed and wounded. The incalculable number of lives was saved as a result of medical care. Many of the advances that were made after the war concluded is a silver lining of hope which has been in parallels of our current strength with COVID 19. Covid-19 is an infectious condition which means it can spread directly or indirectly. There is a growing concern and perceived threat about corona virus among common citizens. The worst part of this scene is no effective management have been shaped to mitigate this disease. As of now along with this standard Covid 19 treatment protocol, a few traditional interventions are being incorporated.

\section{COVID -19 $\backslash$ SARS}

SARS(severe acute respiratory syndrome)is a communicable viral disease caused by new strain of coronavirus).Most common symptoms in patient's progression to SARS include Fever, malaise, chills, headache, myalgia, dizziness, cough, sore throat, difficulty in breathing and running nose. Its incubation period is estimated to be 2 to 7 days commonly 3 to 5 days.

\section{Modes of Transmission}

Transmission appears to be through direct /indirect contact of mucous membrane of eyes, mouth or nose with respiratory droplets or vomitus.

The virus can survive for hours on common surfaces outside the human body and up to four days in human waste. The virus can survive at least for 12 hours on a plastic surface at room temperature and can live for extended periods in cold.

\section{Prevention}

The best ways of preventing this infection is breaking the chain, enhancing an individual's immunity and identifying infection, early and timely medical care.

\section{Concept of COVID according to Ayurveda}

According to Ayurveda, the terminology given to the Pandemic is Janapadodhvamsa ${ }^{1}$ and infectious disease has been under the title of Samkramika Rogas. As per the versus given in Charaka Samhitha, deranged Vayu (air), Jala (water), Desha (locality) and Kaal (season) is responsible for the spread of disease in such large scale. The main reasons leading to the same are improper disposal of waste, air pollution, distribution of polluted water, indulgence in unhealthy and unwholesome activities. We can clearly define these reasons for the present scenario spreading. In those mentioned social conditions, manifestation of symptoms like fever, cough, breathlessness etc. as per classics. In Ayurvedic perspective, the initial phase of the disease can be compared to Agantuja, Vata Kaphaj Jwara and in the succeeding stage, it can vitiate other Doshas and Dhatus entering into Sannipatik condition. In short, we can interpret the COVID 19 disease, according to Ayurvedic perspective in 3 stages viz: -

First stage- Swasa-Kasa symptoms with Jwara (COVID19 positive/negative with mild symptoms.)

Second stage - Vata KaphajJwara (COVID19 positive with specific symptoms at moderate level.)

Third stage- Vata Kaphaj Sannipathik Jwara (COVID 19 positive with severe respiratory distress and associated symptom).

We can consider 4 target groups for easy recognition and treatment of subjects: 
1) Group 1-Quarantine and home isolation subjects with or without corona positive test and health workers and patients -Preventive Treatment.

2) Group 2 - Subjects with mild, severe symptomatology and co-morbid conditions. - Curative and symptomatic treatment

3) Group 3- Vulnerable subjects (pregnant and lactating women, children, geriatric subjects) - Integrated care (Existing medicine along with Ayurveda management under regular observation.)

4) Group 4 - Post treatment restorative healthcare treatments for recovery and rejuvenation. Ayurveda management is said to be "Add On" to the present contemporary line of management.

For Group 1, Ayurveda's intensive information on preventive care drives through the vastness of Dinacharya (daily regime) and Ritucharya (seasonal regime) to maintain healthy life. The simplicity of awareness about oneself and the harmony each one can achieve by uplifting and maintaining their immunity is highly emphasized across Ayurveda's classical scriptures. The main aim of Ayurveda is Swasthasya Swasthyarakshanam ${ }^{2}$ which accounts for prevention of diseases. For Vyadhikshamatva, Ojas is responsible and it is achieved by two approaches -Vyadhi Bala Virodhitva and Vyadhyutpadaka Pratibandhakatva. Among them Vyadhibala Virodhitva is achieved by improving the immunity of the individual's body, while Vyadhyutpadaaka Pratibandhakatva is achieved by antiviral recipes, where in Rasayana and Vajikarana drugs like Guduchi, Ashwagandha, Amalaki, Haridra and Tulsi play a major role. Along with the single drugs, many formulations are also advised like Chyawanaprashavaleha, Drakshavaleha, Indukantham ghrtam, Aravindasavam, Haridra khanda etc. Preventive measures include mainly staying hygiene, social distancing, proper nutrition should be provided considering individual's digestive power. In diet, frequent warm liquids treated with medicinal herbs (preferably Shunthi, Dalchini, Trikatu) should be used as a regular drink to maintain hydration. Deepana $\mathrm{Pa}$ chana drugs like Shadanga Paneeya may be used in case of diarrohea, vomiting or loss of appetite. Preferred vegetables and fruits which can be taken
Shigru, Patola, Karavellaka, Patha, Jeevanthi, Tanduliyak, Mudga, Draksha, Kapitha, Lasuna, Dadima etc Exercise and meditation, Yogasana and Pranayama at least 30 minutes is advised to reduce the related stress that could occur. Adequate sleep for 7-8 hours at night is advised. Self-medication should be avoided. Gandusha/Kavala that is oil pulling or holding oil in mouth for some duration also has a tremendous effect in getting rid of the virus. It can be done with warm water mixed with Ajamoda, Haridra Lavana, Triphala, Yashtimadhu. With these personal hygiene measures, environmental cleanliness should also be maintained. Dhoopana (fumigation) is advised in this regard with antimicrobials such as neem leaf, Karpoora etc. As per classics, Aparajitha Dhoopa ${ }^{3}$ is the best option given for Dhoopana in Jwara Chikitsa.

Group 2: Patients with Mild to Severe Symptoms, Co Morbid Conditions and Immune Compromised In uncomplicated cases, where clinical manifestation include fever, cough, sore throat, nasal congestion etc., first line of treatment should be Jwarahara, Andangamarda hara which can be given like Mahasudarsana Ghana vati (500 mg TDS), Visamajwaranthaka Katha, Pathyadi Kashaya, Guduchyadi Kashayam, Drakshadi Kashayam, Sanjeevani Vati (125 mg TDS), Samshamani Vati (500 mg TDS), Talisadi Churna, Sitopladi Churna etc. In cases of Swasa Kasa predominancy, Vyaghriharitaki Leha, Agasthya Rasayana, Kanthakakari Avaleha can be given along with Dasamoolakatutrayam Kashayam, Amritarishtam, Swasakuthara Rasa. Associated with myalgia, Aswagandharishta, Balarishta, Rasnasaptaka Kada will prove effective. In Pneumonia associated with breathing difficulty, Danwantharam Gutika, Sameerapannga rasa, Dashmoolarishta, Dashamoolasava can be prescribed. Local application of Saindhvadi Taila to chest followed by fomentation gives good results.

Group 3: Pregnant Lactating Women, Children and Geriatric Subjects.

These group of people are particularly vulnerable to any health disasters and they face relatively high risk of the disease burden associated with emergencies. They need special care in terms of prevention and 
management and the best way is boosting immunity by Rasayanas.

For children Indukantham Ghritam,Kalyanaka Ghrtam, Aravindhasvam can be given 5-10 $\mathrm{ml}$ in two divided doses with warm milk or water. For pregnant and lactating women, Phala Sarpis,Kalyanaka Ghrita, Ashwagandha Rasyana can be given. 10-12 gm in two divided doses with warm water. Daily use of milk with ghee is also advised.

Group 4: Post Treatment Restorative Healthcare Along with the daily spikes in confirmed coronavirus cases and deaths, a third more hopeful number is also ticking upward, the number of patients who have recovered from COVID 19.To overcome COVID 19 , comes up with a growing number of questions like does it means about a patient's contagiousness, subsequent immunity to the disease, or long-term effects.

In Ayurveda also, a Concept of PUNARAVARTAKA $J W A R A^{4}$ has been mentioned in which it tells that if a person who had suffered from fever just, follows irregular diet and regimen, again it will contribute to Jwara ; as there will be Dhatu Soshana and Agnimandya Avastha. So, for that, Dhatuposhana and Rasayana Sevana with drugs like Draksha (Vitis vinifera) and Vasa (Adathoda vasica) for at least 45 days and to combat the residual effects of the virus on the body. Antimicrobial and antiviral measures (Vishagna Chikitsa) has to be adopted. It's done with Shirisha or Haridra Churna after clinical recovery. Kriminashaka therapy like usage of Vilwadi Gulika, Dushivishari Gulika, Neelitulasyadi Kashayam, Vidanga Choornam can also be used. Hepato protective and renal protective drugs like Amalaki Choorna or Bhumyamalki Churna should be given to combat toxicity produced from anti-viral drug therapy.

\section{DISCUSSION}

COVID-19 is a new disease, and therefore its details of spreading are still under investigation. It spreads easily between people easier than influenza but not as easily as measles. The typical incubation period for COVID-19 is five or six days, but it can range from one to fourteen days with approximately ten percent of cases taking longer.Early symptoms may include a wide variety of symptoms but infrequently involves shortness of breath which usually develops several days after initial symptoms. Shortness of breath that begins immediately along with fever and cough is more likely to be anxiety than COVID-19. The most critical days of illness tend to be those following the development of shortness of breath. The measures recommended to prevent infection include frequent hand washing, maintaining physical distance from others (especially from those with symptoms), quarantine (especially for those with symptoms), covering coughs, and keeping unwashed hands away from the face. The use of face masks has been encouraged in public settings to minimise the risk of transmissions. The proven traditional ways of Ayurve$d a$ have long way to do in this scenario by improving immunity and to provide effective interventional ways of prevention.

\section{CONCLUSION}

Covid- 19 is an illness due to novel corona virus 2, also known as SARS COV2. It was declared as pandemic by WHO on 11 March 2020.Ayurveda has unique methods of approaching a newly detected disease. It has a three-pointed approach in dealing with the disease - the natural history of the disease (vikara prakrithi), the site of the pathological process (adhishtanam), and etiological features (samutthana visesham). In this article, a brief insight on ayurvedic management of the disease has been explained.

\section{REFERENCES}

1. Charak Samhita, English Translation of Chakrapani Dutta's Ayurveda Dipika, Published By Chowkhambha Sanskrit Series Office, Varanasi Edited By Dr. Ram Karan Sharma And Vaidya Bhagwan Dash Volume II, Sixth Edition 2000, Pp 597, Pg No 142.

2. Charak Samhita, Hindi Translation of Vidhyotini Vyakhyopta, Published By Chaukhambha Bharti Academy, Varanasi, Edited By Vd. Kashinath Pandey And Vd. Gorakhnath Chaturvedi, Purvardha, Edition Reprint 2003, Pp 1024, Page No 187

3. Ashtanga Hrdayam, English Translation, Published By Krishnadas Academy, Varanasi, Edited By Prof K.R. 
Srikantha Murthy, Edition Fifth, Year 2003, Page No 202

4. Charak Samhita, English Translation of Chakrapani Dutta's Ayurveda Dipika, Published By Chowkhambha Sanskrit Series Office, Varanasi Edited By Dr. Ram Karan Sharma And Vaidya Bhagwan Dash Volume III, Reprint Edition 2005, Pp 632, Pg No 218.

\section{Source of Support: Nil}

\section{Conflict of Interest: None Declared}

How to cite this URL: Sreelakshmi S et al: An Insight Into Ayurvedic View Of SARS-Covid-19. International Ayurvedic Medical Journal \{online\} 2020 \{cited July, 2020\} Available from: http://www.iamj.in/posts/images/upload/3925_3929.pdf 